University of Nebraska - Lincoln

DigitalCommons@University of Nebraska - Lincoln

West Central Research and Extension Center, North Platte

Agricultural Research Division of IANR

3-2011

\title{
Invasive plant species as potential bioenergy producers and carbon contributors
}

\author{
Stephen L. Young \\ University of Nebraska - Lincoln, steve.young@usu.edu \\ Gayathri Gopalakrishnan \\ Argonne National Laboratory \\ Deepak R. Keshwani \\ University of Nebraska - Lincoln, dkeshwani2@unl.edu
}

Follow this and additional works at: https://digitalcommons.unl.edu/westcentresext

Part of the Agriculture Commons

Young, Stephen L.; Gopalakrishnan, Gayathri; and Keshwani, Deepak R., "Invasive plant species as potential bioenergy producers and carbon contributors" (2011). West Central Research and Extension Center, North Platte. 20.

https://digitalcommons.unl.edu/westcentresext/20

This Article is brought to you for free and open access by the Agricultural Research Division of IANR at DigitalCommons@University of Nebraska - Lincoln. It has been accepted for inclusion in West Central Research and Extension Center, North Platte by an authorized administrator of DigitalCommons@University of Nebraska - Lincoln. 


\title{
FEATURE Invasive plant species as potential bioenergy producers and carbon contributors
}

\author{
Stephen L. Young, Gayathri Gopalakrishnan, and Deepak R. Keshwani
}

\section{CURRENT CELLULOSIC BIOENERGY SOURCES}

In the United States, bioenergy sources are being investigated in an effort to reduce dependence on foreign oil and the associated risks to national security and climate change (Koh and Ghazoul 2008; Demirbas 2007; Berndes et al. 2003). Multiple sources of renewable plant-based material have been identified and include agricultural and forestry residues, municipal solid waste, industrial waste, and specifically grown bioenergy crops (Demirbas et al. 2009; Gronowska et al. 2009). These sources are most commonly converted to energy through direct burning, conversion to gas, or conversion to ethanol. Annual crops, such as corn (Zea Mays L.) and sorghum grain, can be converted to ethanol through fermentation, while soybean and canola are transformed into fatty acid methyl esters (biodiesel) by reaction with an alcohol (Demirbas 2007). Perennial grasses are one of the more viable sources for bioenergy due to their continuous growth habit, noncrop status, and multiple use products (Lewandowski el al. 2003). In addition, a few perennial grass species have very high water and nutrient use efficiencies producing large quantities of biomass on an annual basis (Dohleman et al. 2009; Grantz and Vu 2009).

Cellulosic bioenergy research is widespread throughout the country (figure 1) and has resulted in a proliferation of studies examining switchgrass (Panicum virgatum L.) in cropping systems (Sanderson et al. 2006). The major focus of current switchgrass research is on production and establishment (Bhandari et al. 2008;

Stephen L. Young is a weed ecologist and an assistant professor in the Department of Agronomy and Horticulture at the University of Nebraska-Lincoln, North Platte, Nebraska. Gayathri Gopalakrishnan is a researcher at the Energy Systems Division, Argonne National Laboratory, Argonne, Illinois. Deepak R. Keshwani is a bioenergy engineer and an assistant professor at the Department of Biological Systems Engineering, University of Nebraska-Lincoln, Lincoln, Nebraska.
Brenner and Moore 2008; Butler et al. 2008; West et al. 2008), with other studies on the effects of switchgrass growth on carbon and nitrogen cycles (Parrish and Lemus 2008), diversity of species mixes containing switchgrass (Staggenborg and Propheter 2008), and the breeding/genetics of switchgrass biotypes (Samuels et al. 2008). In addition to switchgrass, research in the United States is being conducted on many other cellulosic crops, such as Miscanthus giganteus, hybrid poplar (Populus hybrids), and reed canarygrass (Phalaris arundinacea L.) (Sanderson and Adler 2008). To date, little research has been conducted on existing (noncultivated) bioenergy sources (e.g., invasive plant species) from noncrop agricultural land (e.g., marginal and riparian areas).

\section{INVASIVE PLANT SPECIES ESTABLISHMENT}

Nonnative invasive plant species have become established in most North American landscapes. In the western
United States, invasive plant species dominate many of the major river systems, including the Colorado (saltcedar [Tamarisk spp.]), San Joaquin (giant reed [Arundo donax L.]), and Rio Grande (perennial pepperweed [Lepidium latifolium L.]) river systems (Ringold et al. 2008; Shafroth et al. 2008; Spencer et al. 2008; Stromberg et al. 2007; Nagler et al. 2005; Renz and Blank 2004). Across the United States and Canada, purple loosestrife (Lythrum salicaria L.) and nonnative common reed (Phragmites australis [Cav.] Trin. ex Steudel), hereafter referred to as common reed, have been more widespread, invading and establishing in most of the major river systems (Meyerson et al. 2010; Carlson et al. 2009; Miller et al. 2009; Knezevic et al. 2008; Laba et al. 2008; Whyte et al. 2008; Denoth and Myers 2007; Anderson et al. 2006; Lindgren 2006; Herrick and Wolf 2005; Knezevic et al. 2004).

A case in point is the Platte River that bisects the state of Nebraska and is currently infested with several invasive plant

\section{Figure 1}

Locations for bioenergy feedstock research in the United States (USDOE EERE 2008).

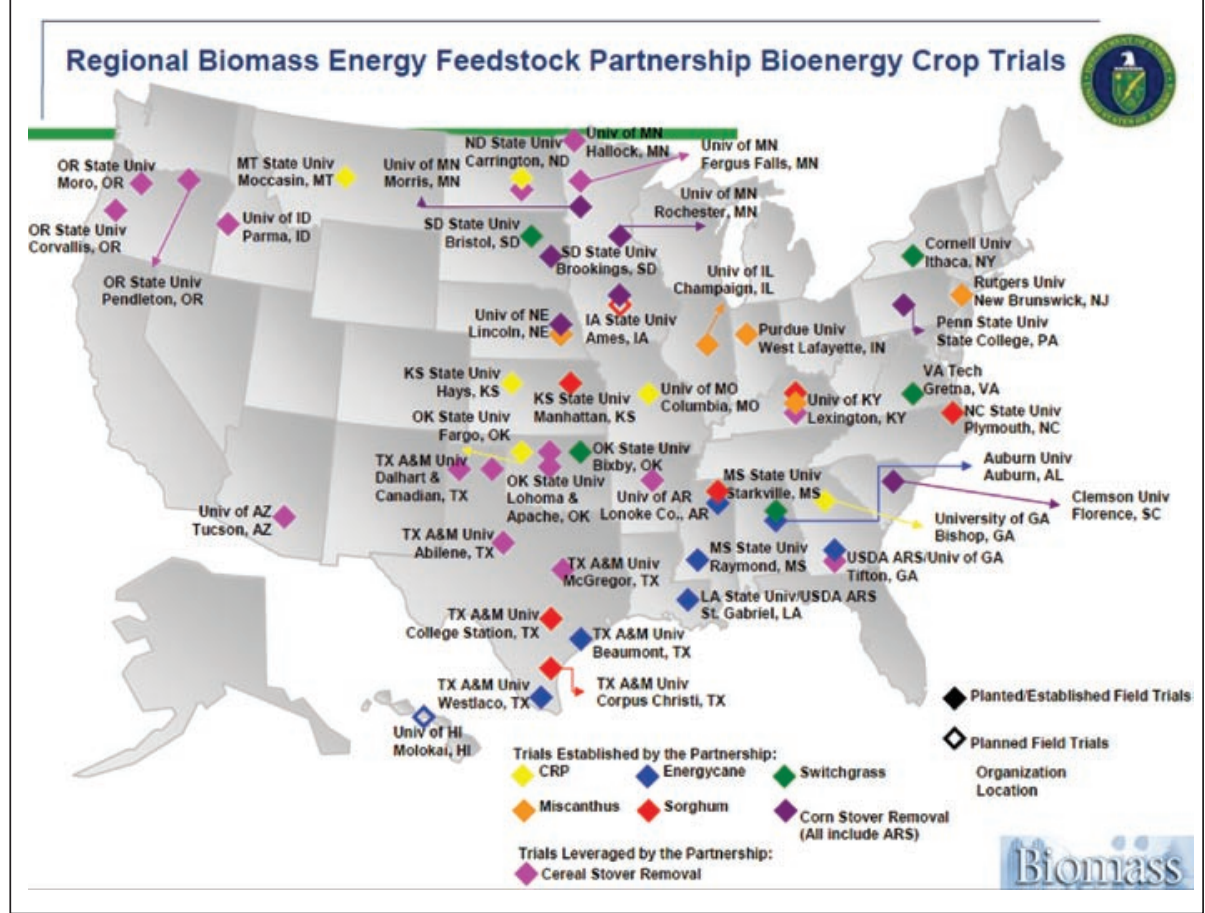


species (Narumalani et al. 2009; Wilson 2009; Wilson and Bernards 2009; Hoffman et al. 2008; Knezevic et al. 2008; Wilson and Knezevic 2007; Roeth et al. 2003). Common reed, one of the most dominant and prolific biomass producers, has established in the Platte River and throughout much of the North American continent (figure 2). It was first introduced to North America in the 1800s and is now established in all states, except Alaska and Hawaii, occurring mainly in or near waterways and riparian areas. Common reed grows perennially with stem densities greater than 150 stems $\mathrm{m}^{-2}$ (14 stems $\left.\mathrm{ft}^{-2}\right)$, canopy that routinely reaches $3 \mathrm{~m}(9.8 \mathrm{ft}$ ) or more (Rapp and Knezevic 2010), and yields of up to $10 \mathrm{Mt} \mathrm{ha}^{-1}\left(5 \mathrm{tn} \mathrm{ac}^{-1}\right)$ (Bjork and Graneli 1978). In 2008, the heaviest populations of common reed in Nebraska could be found starting in North Platte along the Platte River and stretching over $400 \mathrm{~km}(250$ miles) east to the Missouri River (figure 2) (Knezevic et al. 2008).

\section{INVASIVE PLANT SPECIES IMPACTS}

The losses associated with established invasive plant species are substantial, with estimates of almost $\$ 120$ billion per year in the United States (Pimentel et al. 2005). Of the 25,000 nonindigenous plant species, the cost to control nonnative aquatic invaders is over $\$ 100$ million per year. Purple loosestrife alone accounts for annual control costs and forage losses of close to $\$ 50$ million (Pimentel et al. 2005). In addition to the direct losses to agriculture, forestry, recreation, and threats to human health from invasive plant species, nontangible items, such as biodiversity, ecosystem services, and aesthetics are also impacted by invasive plant species (Pejchar and Mooney 2009). Recreational access and aesthetic qualities can be severely hampered by the establishment of invasive plant species (Boylen et al. 2006; Henderson et al. 2006; Colautti et al. 2006).

The establishment of invasive plant species can have many negative effects on the native plant species and environmental conditions. Mortenson et al. (2008) found that the presence of saltcedar indirectly impacts the hydrologic conditions in Grand Canyon National Park through the selective use of native woody competitors

\section{Figure 2}

Map of the Platte River watershed, including the North Platte and South Platte tributaries, based on US Geological Survey data (Courtesy of Karl Musser, Geographer/ Web Developer, Paradigm Systems GIS Inc., Bowie, Maryland).

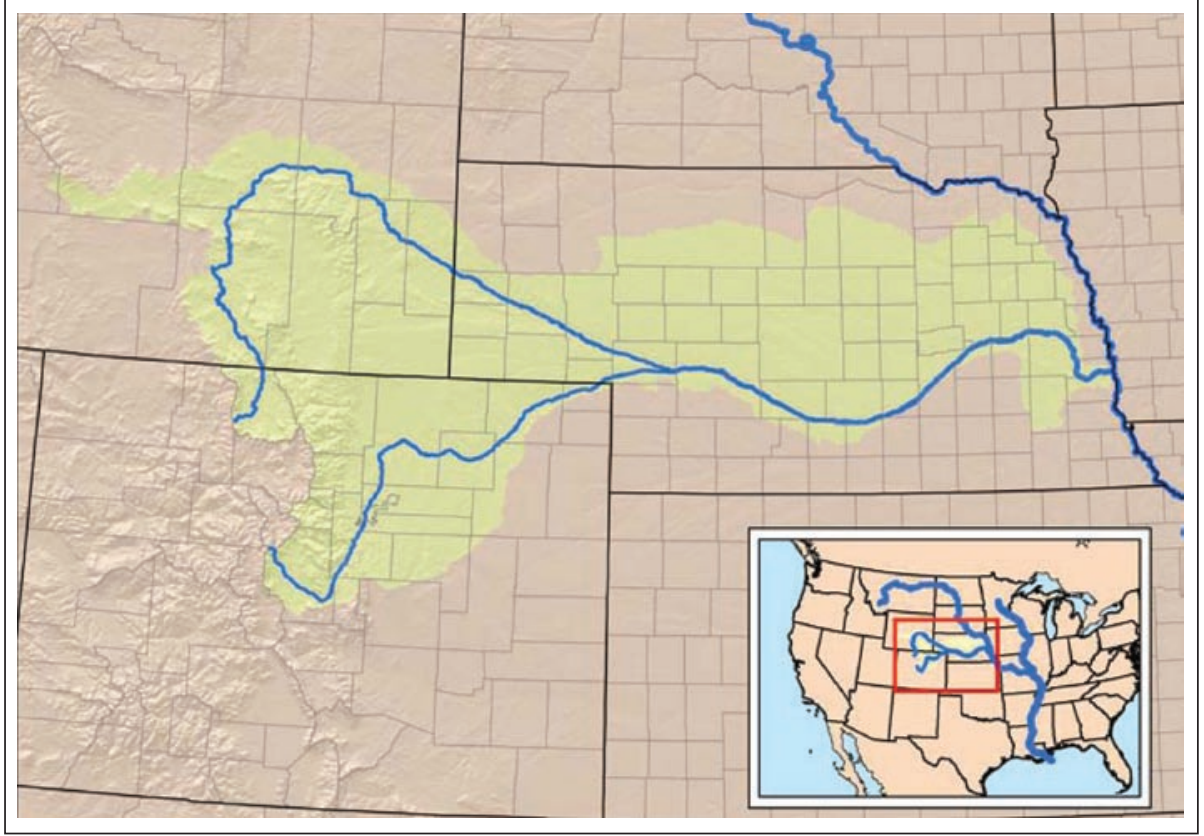

by beavers. The establishment of invasive plant species can affect surface water flow in arid and semiarid climates. Reed et al. (2005) and Murphy et al. (2008) show that native grasslands have less runoff due to high amounts of litter, dead standing herbage, and ground cover, which is in direct contrast to the annual grass dominated landscapes of the Pacific and Intermountain regions of western United States. Other studies give evidence supporting the deleterious effects of invasive plant species establishment on plant diversity (Reinhart and Callaway 2006; Dukes 2001; Mullin 1998) and soil nutrient cycles (Weidenhamer and Callaway 2010; Raizada et al. 2008; Ehrenfeld 2003).

Individual plant species can modify soil nutrients through multiple processes and hence impact the global biochemistry. As plants take up nutrients for growth, the incorporation of nutrients into stable organic material results in the sequestration of important elements, such as carbon. However, they also impact belowground mineral pools through chemicals exuded from the roots (exudates), decomposition of leaf litter of differing chemical quality, and nutrient and carbon mineralization rates (Tilman et al. 1997; Hooper and
Vitousek 1998; Ehrenfeld 2003; Chapin et al. 2000).

Prior research has indicated that invasive plant species may alter nutrient cycles in ways that are different from native species (Weidenhamer and Callaway 2010). Allison and Vitousek (2004) showed that the leaf areas, growth rates, and leaf nutrient concentrations are significantly higher in invasive plants compared to native species and these traits could increase rates of litter decomposition and nutrient cycling. Ehrenfeld (2003) and Wolfe and Klironomos (2005) indicated that invasive plant species often increase carbon inputs into the ecosystem as a result of greater primary production and thus alter processes governing carbon and nutrient cycles. Changes in plant species also affect the soil microbial communities and hence the carbon and nutrient cycles (Kourtev et al. 2002; Ravit et al. 2006). Further, Hamilton and Frank (2001) have suggested that grazing of invasive plant species by herbivores influences root exudates and hence soil carbon structure. Similar results may be obtained if invasive plant species, such as common reed, are harvested to produce bioenergy. Much of the research on invasive plant species to date has been 
at the field scale, when the plant is already present in the ecosystem as an invasive. Effects of the invasive species on native species, growth, harvesting, and impact on greenhouse gas emissions and hydrology have received limited research.

\section{INVASIVE PLANT SPECIES BIOENERGY POTENTIAL}

The widespread distribution and high rate of biomass production (10 to 30 oven dry Mt ha $\mathrm{a}^{-1}$ [5 to $15 \mathrm{tn} \mathrm{ac}^{-1}$ ), particularly for species located near water sources (e.g., riparian areas, lakes, and coastal bodies), make invasive plant species, like common reed, a viable bioenergy source (figure 3). This fact has largely been ignored by many biofuel advocates and disputed by invasion biologists (Davis et al. 2008; Simberloff 2008).

In the near future, most of the biomass for energy is predicted to come from urban, forest, and agricultural residues, particularly from cereal grains or from crops grown specifically for biomass-based energy production (Perlack et al. 2005; USDOE EIA 2010). While crop residues are of interest because they are produced in major regions across the United States and are available at reasonable prices (Graham et al. 2007), invasive plant species are free for the taking and grow everywhere, including marginal lands that are currently under consideration for producing crop residues (Brown 2007; Tilman et al. 2006).

When consideration is given for invasive plant species as bioenergy sources, most opponents raise concerns about anthropogenic movement (i.e., transportation) and establishment (i.e., crops) of invasive plant species (Cousens 2008; Simberloff 2008). In a forum paper by Barney and DiTomaso (2008), the words 'cultivation' and 'crop' were used repeatedly to describe the threats that nonnative invasive species pose when being considered for use as a bioenergy source. The discussion of invasive plant species solely in the context of cropping systems fails to consider the potential for using existing stands of invasive plant species as a bioenergy source. Ideally, biofuel crops should be propagated in containable systems, and fundamental research needs to be conducted to identify traits that reduce the risk of biological invasion (DiTomaso

\section{Figure 3}

Common reed distribution in the United States and Canada (Utah State University 2007).
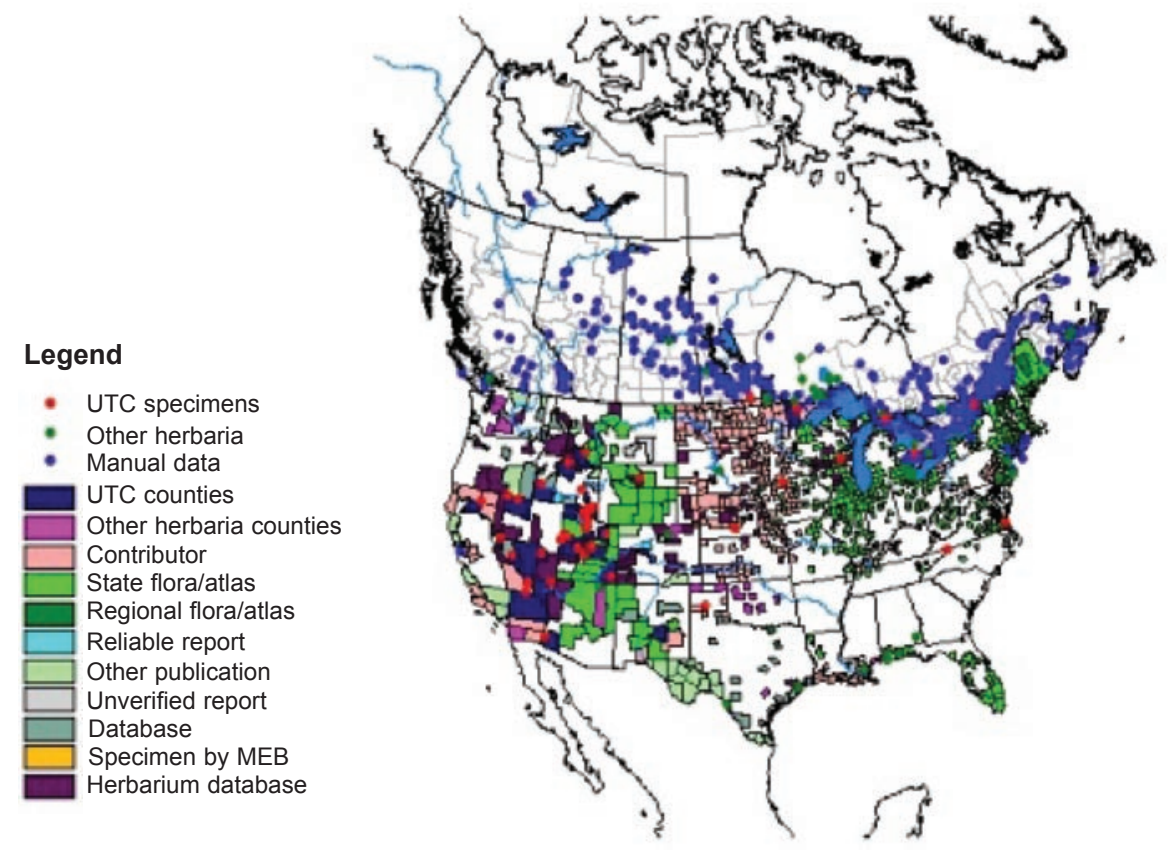

et al. 2010). Unfortunately, the ideal system does not exist, but what does exist is increasing populations of invasive plant species that are expanding their range and extending their devastating effects on the environment and economy.

What is noticeably absent in the literature are studies on the use of existing (i.e., noncultivated) invasive plant species populations as bioenergy sources. This approach does not advocate the cultivation or proliferation of new or novel crops that are nonnative invasive species or possess invasive characteristics. Studies continue to document increasing rates of spread and distribution of invasive plant species (Duncan et al. 2004) with little evidence of control efforts that have significantly or permanently reduced large infestations of invasive plant species. A management approach that results in the containment or reduction of existing stands of invasive plant species is a main tenant founded in the principles of weed science (Radosevich et al. 1997; Ross and Lembi 1985) and is fully supported by the authors of this paper.

The literature is clear that significant amounts of biomass can be produced by perennial plant species, native and nonnative (Sanderson and Adler 2008). However, there are no studies that have investigated how invasive plant species might be managed in a total systems approach that seeks to reduce invasive plant species in the environment and supply either a liquid, drop-in biofuel or a dry matter source for facilities with biomass heating and cooling systems.

\section{USE OF INVASIVE PLANT SPECIES FOR BIOENERGY}

There is an absence of scientific studies on the use of invasive plant species in biomass heating and biomass furnace technology. Wood products are used in biomass burning facilities. Wood is readily converted to a useable form for burning in boilers by chipping, shredding, or pelleting, which also eases the transport and storage requirements. In parts of the United States, native perennial grasses are grown for use as pellets in wood stoves and wood burning facilities (Samson et al. 2005). While the harvesting of native perennial grasses in an agricultural setting is different than harvesting of invasive plant species in noncrop areas, the process is similar and worth consideration.

Existing knowledge on ethanol production potential of invasive plant species 
(e.g., common reed) is limited. Szijarto et al. (2009) reported 83\% cellulose conversion of common reed into soluble sugars, and after fermentation, final ethanol yields were reported to be $73 \%$ of theoretical maximum. Sathitsuksanoh et al. (2009) used a solvent-based fractionation approach to achieve similar yields of fermentable sugars from common reed. While these results are promising, the pretreatment methods are reported to be prohibitively expensive due to chemical costs (Sun and Cheng 2002; Alvira et al. 2010).

\section{THE FUTURE OF INVASIVE PLANT SPECIES BIOENERGY}

Among recent advances in developing cellulosic and noncellulosic biofuel sources, corn, switchgrass, and others (e.g., camelina, canola) have risen to the top. In surveying the landscape, a potentially promising new area of bioenergy production exists-invasive plant species. The addition of invasive plant species as a bioenergy source will help to diversify the nation's energy dependence and help in the reduction of the negative environmental and social impacts from energy crop production. In addition, belowground carbon stores may provide an opportunity to reduce the impacts associated with global climate change.

In the agriculture sector, harvesting equipment is well advanced for facilitating efficient crop production on both small and large scales. In noncrop systems, the number of limitations and lack of need have slowed the progress of equipment development for biomass harvesting (Graneli 1984). The lack of economic return is an important reason for less intensive management in noncrop areas. With new markets emerging for cellulosic energy sources and advances in equipment technology, this increased incentive could help improve the level of management of invasive plant species in noncrop areas and subsequent harvest or removal of excess biomass.

Using invasive plant species in bioenergy facilities would provide enticing opportunities for land managers and business developers. Since the primary focus of most invasive plant species management is on control of unwanted vegetation, the massive amounts of biomass from high cellulosic plants creates a challenge for disposal. Research has shown that piling or dispersing cut portions of many woody and herbaceous invasive plant species can result in the reestablishment by new plants from propagule segments (Boose and Holt 1999; Decruyenaere and Holt 2001). With advances in processing equipment, invasive plant species biomass could be processed into pellets for transporting to facilities that burn biomass or convert biomass to liquid biofuels. The processing of invasive plant species into a useable form (i.e., pellets) that does not promote the spread or introduction of unwanted vegetation minimizes the risks of environmental contamination and provides an economic opportunity for business development in rural communities.

While corn and switchgrass are the leading plant candidates for biofuel production, they may not be the most sustainable. Alternatively, the removal of existing invasive plant species biomass and processing into pellets for combustion or liquid fuel conversion maybe more sustainable as it would comply with the US Executive Order 13112 on invasive species (Clinton 1999), support climate change initiatives (Crowl et al. 2008), and expand economic opportunities in rural areas by helping fulfill the mandate by the US Renewable Fuels Standards (USDA 2010).

\section{REFERENCES}

Allison, S.D., and P.M. Vitousek. 2004. Rapid nutrient cycling in leaf litter from invasive plants in Hawai'i. Oecologia 141:612-619.

Alvira, P., E. Tomás-Pejó, M. Ballesteros, and M. J. Negro. 2010. Pretreatment technologies for an efficient bioethanol production process based on enzymatic hydrolysis: A review. Bioresource technology 101(13):4851-4861.

Anderson, R.P., A.T. Peterson, and S.L. Egbert. 2006. Vegetation-index models predict areas vulnerable to purple loosestrife (Lythrum salicaria) invasion in Kansas. Southwestern Naturalist 51(4):471-480.

Barney, J.N., and J.M. DiTomaso. 2008. Nonnative species and bioenergy: Are we cultivating the next invader? BioScience 58:64-70.

Berndes, G., M. Hoogwijkb, and R. van den Broek. 2003. The contribution of biomass in the future global energy supply: a review of 17 studies. Biomass and Bioenergy 25:1-28.

Bhandari, H., B. Narasimhamoorthy, M. Saha, D. Wood, and J. Bouton. 2008. Two methods of selecting parents to produce high yielding, lowland switchgrass synthetic cultivars. In Proceedings of the 50th International American Society of Agronomy-Crop Science Society of AmericaSoil Science Society of America Annual Meeting, Houston, Texas, October 5-9, 2008.

Bjork, S., and W. Graneli. 1978. Energy reeds and the environment. Ambio 7:150-156.

Boose, A.B., and J.S. Holt. 1999. Environmental effects on asexual reproduction in Arundo donax. Weed Research 39:117-127.

Boylen, C.W., L.W. Eichler, J.S. Bartkowski, and S.M. Shaver. 2006. Use of geographic information systems to monitor and predict non-native aquatic plant dispersal through north-eastern North America. Hydrobiologia 570:243-248.

Brenner, D., and K.J. Moore. 2008. Winter sweetclover to improve sustainable switchgrass biomass production. In Proceedings of the 50th International American Society of AgronomyCrop Science Society of America-Soil Science Society of America Annual Meeting, Houston, Texas, October 5-9, 2008.

Brown, L.R. 2007. Distillery demand for grain to fuel cars vastly understated: World may be facing highest grain prices in history. http://www.earth-policy.org/index. php?/plan_b_updates/2007/update63.

Butler, T., C. Huo, and J. Guretzky. 2008. Effects of planting date, seeding rate, and row spacing on lowland switchgrass establishment. In Proceedings of the 50th International American Society of Agronomy-Crop Science Society of AmericaSoil Science Society of America Annual Meeting, Houston, Texas, October 5-9, 2008.

Carlson, M.L., K.P. Kowalski, and D.A. Wilcox. 2009. Promoting species establishment in a Phragmitesdominated Great Lakes coastal wetland. Natural Areas Journal 29:263-280.

Chapin, F.S., E.S. Zavaleta, V.T. Eviner, R.L. Naylor, P.M. Vitousek, H.L. Reynolds, D.U. Hooper, S. Lavorel, O.E. Sala, S.E. Hobbie, M.C. Mack, and S. Díaz. 2000. Consequences of changing biodiversity. Nature 405:234-242.

Clinton, W.J. 1999. Executive Order 13112 of 3 February 1999. Invasive Species. 8 February 1999/ Presidential Documents. Federal Register 64(25):6183-6186

Colautti, R.I., S.A. Bailey, C.A. van Overdijk, K. Amundsen, and H.J.MacIsaac.2006. Characterised 
and projected costs of nonindigenous species in Canada. Biological Invasions 8:45-59.

Cousens,R. 2008. Risk assessment of potential biofuel species: an application for trait-based models for predicting weediness? Weed Science 56:873-882.

Crowl, T.A., T.O. Crist, R.R. Parmenter, G. Belovsky, and A.E. Lugo. 2008. The spread of invasive species and infectious disease as drivers of ecosystem change. Frontiers in Ecology and the Environment 6:238-246.

Davis, A.S., D.C. Brainard, and E.R. Gallandt. 2008 Introduction to the invasive plant species and the new bioeconomy symposium. Weed Science 56:866.

Decruyenaere, J.G., and J.S. Holt. 2001. Seasonality of clonal propagation in giant reed. Weed Science 49:760-767.

Demirbas, A. 2007. Progress and recent trends in biofuels. Progress in Energy and Combustion Science 33:1-18.

Demirbas, M.F., M. Balat, and H. Balat. 2009 Potential contribution of biomass to the sustainable energy development. Energy Conversion and Management 50:1746-1760.

Denoth, M, and J.H. Myers. 2007. Competition between Lythrum salicaria and a rare species: combining evidence from experiments and longterm monitoring. Plant Ecology 191(2):153-161.

DiTomaso, J.M., J.K. Reaser, C.P. Dionigi, O.C Doering, E. Chilton, J.D. Schardt, and J.N. Barney. 2010. Biofuel vs bioinvasion: seeding policy priorities. Environmental Science and Technology 44:6906-6910.

Dohleman, F.G., E.A. Heaton, A.B. Leakey, and S.P. Long. 2009. Does greater leaf-level photosynthesis explain the larger solar energy conversion efficiency of Miscanthus relative to switchgrass? Plant Cell and Environment 32:1525-1537.

Dukes, J.S. 2001. Biodiversity and invasibility in grassland microcosms. Oecologia 126:563-568.

Duncan, C.A., J.J. Jachetta, M.L. Brown,V. Carrithers, J.K. Clark, J.M. DiTomaso, R.G. Lym, K.C. McDaniel, M.J. Renz, and P.M. Rice. 2004 Assessing the economic, environmental, and societal losses from invasive plants on rangeland and wildlands. Weed Technology 18:1411-1416.

Ehrenfeld, J.G. 2003. Effects of exotic plant invasions on soil nutrient cycling processes. Ecosystems 6:503-523.

Graham, R.L., R. Nelson, J. Sheehan, R.D. Perlack, and L.L.Wright. 2007. Current and potential U.S corn stover supplies. Agronomy Journal 99:1-11.

Graneli, W. 1984. Reed (Phragmites asutralis (Cav.) Trin. Ex Steudel) as an energy source in Sweden. Biomass 4:183-208.
Grantz, D.A., and H.B Vu. 2009. O-3 sensitivity in a potential C-4 bioenergy crop: Sugarcane in California. Crop Science 49:643-650.

Gronowska, M., S. Joshi, and H.L. MacLean. 2009. A review of US and Canadian biomass supply studies. Bioresources 4:341-369.

Hamilton, E.W., and D.A. Frank. 2001. Can plants stimulate soil microbes and their own nutrient supply? Evidence from a grazing tolerant grass. Ecology 82:2397-2402.

Henderson, S., T.P. Dawson, and R.J. Whittaker. 2006. Progress in invasive plants research. Progress in Physical Geography 30:25-46.

Herrick, B.M., and A.T. Wolf. 2005. Invasive plant species in diked vs. undiked Great Lakes wetlands. Journal of Great Lakes Research 31:277-287.

Hoffman, J.D., S. Narumalani, D.R. Mishra, P. Merani, and R.G. Wilson. 2008. Predicting potential occurrence and spread of invasive plant species along the North Platte River, Nebraska. Invasive Plant Science and Management 1:359-367.

Hooper, D.U., and P.M. Vitousek. 1998. Effects of plant composition and diversity on nutrient cycling. Ecological Monographs 68:121-149.

Knezevic, S.Z., A. Datta, and R. Rapp. 2008. Noxious weeds of Nebraska: Common reed. University of Nebraska-Lincoln Extension Publication EC-08-166. http://www.ianrpubs.unl.edu/sendIt/ec166.pdf.

Knezevic, S.Z., D. Smith, R. Kulm, D. Doty, D. Kinkaid, M. Goodrich, and R. Stolcpart. 2004. Purple loosestrife (Lythrum salicaria) control with herbicides: Single-year application. Weed Technology 18:1255-1260.

Koh, L.P., and J. Ghazoul. 2008. Biofuels, biodiversity, and people: Understanding the conflicts and finding opportunities. Biological Conservation 141:2450-2460

Kourtev, P.S., J.G. Ehrenfield, and M.M. Hagglom. 2002. Exotic plant species alter the microbial community structure and function in the soil. Ecology 83:3152-3166.

Laba, M., R. Downs, S. Smith, S. Welsh, C. Neider, S. White, M. Richmond, W. Philpot, and P. Baveye. 2008. Mapping invasive wetland plants in the Hudson River National Estuarine Research Reserve using quickbird satellite imagery. Remote Sensing of Environment 112:286-300.

Lewandowski, I., J.O. Scurlock, E. Lindvall, and M. Christou. 2003. The development and current status of perennial rhizomatous grasses as energy crops in the US and Europe. Biomass and Bioenergy 25:335-361.

Lindgren, C.J. 2006. Angler awareness of aquatic invasive species in Manitoba. Journal of Aquatic Plant Management 44:103-108.
Meyerson, L.A., D.V. Viola, and R.N. Brown. 2010.

Hybridization of invasive Phragmites australis with a native subspecies in North America. Biological Invasions 12:103-111.

Miller, R.J., A.D. Carroll, T.P. Wilson, and J. Shaw. 2009. Spatiotemporal analysis of three common wetland invasive plant species using herbarium specimens and geographic information systems. Castanea 74:133-145.

Mortenson, S.G., P.J. Weisberg, and B.E. Ralston. 2008. Do beavers promote the invasion of non native Tamarix in the Grand Canyon riparian zone? Wetlands 28:666-675.

Mullin, B.H. 1998. The biology and management of purple loosestrife (Lythrum salicaria). Weed Technology 12:397-401.

Murphy, S.R., F.J. Larney, W.D. Williams, P.R. DeMaere, and S. Harden. 2008. Surface runoff response of native and introduced grasses under simulated rainfall in southern Alberta. Canadian Journal of Soil Science 88:337-348.

Nagler, P.L., O. Hinojosa-Huerta, E.P. Glenn, J. Garcia-Hernandez, R. Romo, C. Curtis, A.R. Huete, and S.G. Nelson. 2005. Regeneration of native trees in the presence of invasive saltcedar in the Colorado River delta, Mexico. Conservation Biology 19:1842-1852.

Narumalani, S., D.R. Mishra, R.G. Wilson, P. Reece, and A. Kohler. 2009. Detecting and mapping four invasive species along the floodplain of North Platte River, Nebraska. Weed Technology 23:99-107.

Parrish, D.J., and R. Lemus. 2008. Nutrient cycling in switchgrass grown for biomass. In Proceedings of the 50th International American Society of Agronomy-Crop Science Society of AmericaSoil Science Society of America Annual Meeting, Houston, Texas, October 5-9, 2008.

Pejchar, L., and H.A. Mooney. 2009. Invasive species, ecosystem services and human well-being. Trends in Ecology \& Evolution 24:497-504.

Perlack, R.D., L.L. Wright, A.F. Turhollow, R.L. Graham, B.J. Stokes, and D.C. Erbach. 2005. Biomass as feedstock for a bioenergy and bioproducts industry: the technical feasibility of a billion-ton annual supply. US Department of Energy DOE/GO-102995-2135.

Pimentel, D., R. Zuniga, and D. Morrison. 2005. Update on the environmental and economic costs associated with alien-invasive species in the United States. Ecological Economics 52:273-288.

Radosevich, S.R., J.S. Holt, and C. Ghersa. 1997. Weed ecology: implications for management 2nd ed. New York: John Wiley and Sons, Inc. 
Raizada, P.,A.S. Raghubanshi,J.S. Singh. 2008. Impact of invasive alien plant species on soil processes: A review. In Proceedings of the National Academy of Sciences India Section B-Biological Sciences 78:288-298

Rapp, R., and S.Z. Knezevic. 2010. Integrated management of Phragmites australis (common reed) along the Platte River. In Proceedings of the 50th Weed Science Society of America Conference, Denver, Colorado, February 8-11, 2010.

Ravit, B., M.M. Haggblom, and J.G. Ehrenfield. 2006. Salt marsh vegetation species affect rhizosphere microbial community structure and function. Soil Biology and Biochemistry 38:2359-2371.

Reed, H.E., T.R. Seastedt, and J.M. Blair. 2005. Ecological consequences of C-4 grass invasion of a C-4 grassland: a dilemma for management. Ecological Applications 15:1560-1569.

Reinhart, K.O., and R.M. Callaway. 2006. Soil biota and invasive plants. New Phytologist 170:445-457.

Renz, M.J., and R.R. Blank. 2004. Influence of perennial pepperweed (Lepidium latifolium) biology and plant-soil relationships on management and restoration. Weed Technology 18:1359-1363.

Ringold, P.L., T.K. Magee, and D.V. Peck. 2008. Twelve invasive plant taxa in US western riparian ecosystems. Journal of the North American Benthological Society 27:949-966.

Roeth, F., S. Melvin, and I. Schleufer. 2003. Noxious weeds of Nebraska: Musk thistle. University of Nebraska-Lincoln Extension Publication EC-03-176. http://www.ianrpubs.unl.edu/sendIt/ec176.pdf.

Ross, M.A., and C.A. Lembi. 1985. Applied Weed Science. New York: Macmillan Publishing Company.

Samson, R., S. Mani, R. Boddey, S. Sokhansanj, D. Quesada, S. Urquiaga, V. Reis, and C. Ho Lem. 2005. The potential of C4 perennial grasses for developing a global BIOHEAT industry. Critical Reviews in Plant Sciences 24:461-495.

Samuels, T., Y. Wu, C. Taliaferro, and Y. Huang. 2008. PCR amplification of sorghum SSR markers with switchgrass DNA. In Proceedings of the 50th International American Society of AgronomyCrop Science Society of America-Soil Science Society of America Annual Meeting, Houston, Texas, October 5-9, 2008.

Sanderson, M.A., and P.R. Adler. 2008. Perennial forages as second generation bioenergy crops. International Journal of Molecular Sciences 9:768-788.

Sanderson, M.A., P.R. Adler, A.A. Boateng, M.D. Casler, and G. Sarath. 2006. Switchgrass as a biofuels feedstock in the USA. Canadian Journal of Plant Science 86:1315-1325.
Sathitsuksanoh, N., Z.Zhu, N.Templeton,J.A. Rollin, S.P. Harvey, andY.P. Zhang. 2009. Saccharification of a potential bioenergy crop, Phragmites australis (Common Reed), by lignocellulose fractionation followed by enzymatic hydrolysis at decreased cellulase loadings. Industrial \& Engineering Chemistry Research 48:6441-6447.

Shafroth, P.B., V.B. Beauchamp, M.K. Briggs, K. Lair, M.L. Scott, and A.A. Sher. 2008. Planning riparian restoration in the context of Tamarix control in western North America. Restoration Ecology 16:97-112.

Simberloff, D. 2008. Invasion biologists and the biofuels boom: Cassandras or colleagues? Weed Science 56:867-872.

Spencer,D.F., R.K. Stocker, P.S. Liow, L.C.Whitehand, E.G. Ksander, A.M. Fox, J.H. Everitt, and L.D. Quinn. 2008. Comparative growth of giant reed (Arundo donax L.) from Florida, Texas, and California. Journal of Aquatic Plant Management 46:89-96.

Staggenborg, S., and J.L. Propheter. 2008. Direct comparison of biomass yields of annual and perennial biofuel crops. In Proceedings of the 50th International American Society of AgronomyCrop Science Society of America-Soil Science Society of America Annual Meeting, Houston, Texas, October 5-9, 2008.

Stromberg, J.C., S.J. Lite, R. Marler, C. Paradzick., P.B. Shafroth, D. Shorrock, J.M. White, and M.S. White. 2007. Altered stream-flow regimes and invasive plant species: the Tamarix case. Global Ecology and Biogeography 16:381-393.

Sun, Y., and J.Y. Cheng. 2002. Hydrolysis of lignocellulosic materials for ethanol production: A review. Bioresource Technology 83:1-11.

Szijarto, N., Z. Kadar, E. Varga, A.B. Thomsen, M. Costa-Ferreira, and K. Reczey. 2009. Pretreatment of reed by wet oxidation and subsequent utilization of the pretreated fibers for ethanol production. Applied Biochemistry and Biotechnology 155:386-396.

Tilman, D., J. Knops, D. Wedin, B. Peter, M. Ritchie, and E. Siemann. 1997. The influence of functional diversity and composition on ecosystem processes. Science 277:1300-1302.

Tilman, D. J. Hill, and C. Lehman. 2006. Carbonnegative biofuels from low-input high-diversity grassland biomass. Science 314:1598-1600.

USDA (United States Department of Agriculture). 2010. Biofuels strategic production report. USDA. http://www.usda.gov/documents/ USDA_Biofuels_Report_6232010.pdf.

USDOE EIA (United States Department of Energy Energy Information Administration). 2010. Annual energy outlook 2010 with projections to 2035. USDOE EIA. http://www.eia.doe.gov/ oiaf/aeo/pdf/0383(2010).pdf.

USDOE EERE (USDOE Energy Efficiency \& Renewable Energy). 2008. Sustainable Production. USDOE Energy Efficiency \& Renewable Energy Biomass Program. http:// www1.eere.energy.gov/biomass/feedstocks_sustainable_production.html.

Utah State University. 2007. http://herbarium.usu. edu/webmanual.

Weidenhamer, J.D., and R.M. Callaway. 2010. Direct and indirect effects of invasive plants on soil chemistry and ecosystem function. Journal of Chemical Ecology 36:59-69.

West, C.P., K.R. Brye, M.P. Popp, L.R. Oliver, P.A. Beck, and J.L. Schuler. 2008. Site characterization in Arkansas switchgrass trials for biomass production. In Proceedings of the 50th International American Society of Agronomy-Crop Science Society of America-Soil Science Society of America Annual Meeting, Houston, Texas, October 5-9, 2008.

Whyte, R.S., D. Trexel-Kroll, D.M. Klarer, R. Shields, and D.A. Francko. 2008. The invasion and spread of Phragmites australis during a period of low water in a Lake Erie coastal wetland. Journal of Coastal Research 55:111-120.

Wilson, R.G. 2009. Noxious weeds in Nebraska: Canada thistle. University of Nebraska-Lincoln Extension Publication EC-09-171. http://www. ianrpubs.unl.edu/sendIt/ec171.pdf.

Wilson, R.G., and M. Bernards. 2009. Noxious weeds of Nebraska: Russian olive. University of Nebraska Lincoln-Extension Publication EC-09-167. http://www.ianrpubs.unl.edu/sendIt/ec167.pdf.

Wilson, R.G., and S.Z. Knezevic. 2007. Noxious weeds of Nebraska: Saltcedar. University of Nebraska-Lincoln Extension Publication EC-07-164. http://www.ianrpubs.unl.edu/sendIt/ec164.pdf.

Wolfe, B.E., and J.N. Klironomos. 2005. Breaking new ground: soil communities and exotic plant invasions. BioScience 55:477-487. 